Islamiconomic: Jurnal Ekonomi Islam

Volume 12 No. 1 January - June 2021

P-ISSN: 2085-3696; E-ISSN: 2541-4127

Page: 01 - 22

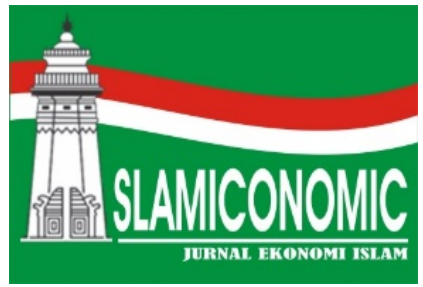

ISLAMICONOMIC: Jurnal Ekonomi Islam

Department of Islamic Economics

Faculty of Islamic Economics and Business

Universitas Islam Negeri Sultan Maulana Hasanuddin Banten

Jalan Jenderal Sudirman No. 30 Serang 42118

BANTEN - INDONESIA

Phone: +62254 200323 || Fax: +62254200022 || Website: www. journal.islamiconomic.or.id

\title{
IMPLEMENTATION OF GREEN SUPPLY CHAIN MANAGEMENT IN HALAL SUPPLY CHAIN MANAGEMENT - A CONCEPTUAL MODEL
}

Fitra Azkiya Firdiansyah, ${ }^{1 *}$ Achmad Rosidi, ${ }^{2}$ Aldi Khusmufa Nur Iman ${ }^{3}$

123 Universitas Islam Negeri Sunan Ampel, Surabaya, Indonesia

${ }^{*}$ Corresponding author: ferdiazkiya@gmail.com

\begin{tabular}{|c|c|c|}
\hline \multicolumn{3}{|c|}{ Information } \\
\hline \multicolumn{3}{|c|}{ Article History: } \\
\hline Received & & 06.03 .2021 \\
\hline Revised & & 28.05 .2021 \\
\hline Accepted & : & 07.06 .2021 \\
\hline
\end{tabular}

Keywords: Halal Industry, Green Industry, Industrial Supply Chain Management

\begin{abstract}
:
Industrial estates are usually reflected in the existence of a certain standardization. The green industrial area was born with Green Supply Chain Management. The halal industry gave birth to Halal supply chain management. So far, there has not been an application of an environmentally friendly concept in the halal industrial area that applies the concept of Halal supply chain management. The concept of Halal supply chain management should complement the existing concepts. This is what the researchers then found a middle way to do by continuing to carry out Halal Supply Chain Management which is also environmentally friendly. This research is a literature study by examining the quality of the study, the process of collecting and sorting data according to the intended object, data analysis, interpretation of the results, and recommendations of the research results. The results of the analysis show that Halal is reflected in Halal Supply Chain Management, while Green Supply Chain Management reflects "thoyyibān" (good) in the environment. The two concepts basically become one unit in "hālalān thoyyībān". So that the results of research with the implementation of environmentally friendly concepts in the supply chain of the halal industry have an additional positive impact in three aspects, namely. Financial, Environmental, and Social.
\end{abstract}




\section{A. INTRODUCTION}

Various aspects of life in the world have been regulated in Islam, as a religion of rahmatan lil alamin. All activities related to the fulfillment of physical desires are also regulated like activities in the economy of the people. However, there are limitations in Islam so that these activities can provide benefits and there is no harm to the body, including our minds. All of that in Islam is known as Halal.

The production process in a company we are familiar with within the industry is supply chain management. This concept was first put forward by Keith Oliver, who is a consultant at Booz Allen Hamilton. Financial Times in 1982 interviewed him and put forward the concept of supply chain management. The concept then expanded and began to be used in several industries, and many researchers began to be interested in developing what he said. (Oliver \& Webber, 2012).

Green industry emerges and is well implemented. The concept of the green industry in its activities regulates productivity and adequacy in the efficient use of resources in order to adapt to technological advances with the times. Maintain natural capacity and provide natural preservation to keep it awake in accordance with the standards that have been set to protect natural ecosystems. This has also been stated in the Law of the Republic of Indonesia Number 3 of 2014 concerning the green industry. (UU. No 3, 2014).

The progress of the halal industry focuses on planning needs that are currently occurring by putting forward five perspectives. Specifically, the main part of the policy regarding the implementation of Halal Product Guarantee (JPH). there has been no confirmation and normalization of halal goods, and there is no guidance in improving the halal industry. In addition, another point of view, especially Human Resources, consists of many producers who do not understand halal products and still need information about halal products for independent business activists. At that point, the third part of implementing the halal industry is that there is no adequate foundation, especially the lack of coordination from policymakers who handle the implementation of the halal industry. The fourth part is not yet about socialization, both counseling and training for micro, small and medium enterprises related to products with halal certification. The last part is that there are many food business 
Fitra Azkiya. F et al.: Implementation of Green Supply Chain...

actors who still rely on imports, the problem is that the halalness of imported goods is not yet known (Yulia, 2015).

There is a growing need to integrate environmentally-friendly industries into halal supply chain management (HSCM) practices. Lack of consumer awareness of the environment so that natural ecosystems are not properly maintained, is also related to industrial development in Indonesia. Tight product competition with low prices and similar products from imports has suppressed the development of environmentally friendly industrial estates in Indonesia. This will result in lagging production processes from other countries that are starting to actively promote environmental issues.

Policymakers who formulate regulations to meet social and ecological interests related to industrial growth do little to help solve environmental issues. The concept of the halal supply chain that is currently developing has not yet answered environmental issues. A concise classification is needed to assist academics, researchers, and practitioners in understanding integrated halal supply chain management from a broader perspective. (Raj et al., 2018).

So those analysts believe that the green industry concept can synergize with the halal industry to support the goodness contained in it. Al-Qur'an in Surah Al-Baqorah verse 168 also clarifies how good should be for us "O you! Eat Halal and good (Thayyib)". It is explained that halal and good are like not haram, have good effects on the body, and damage the mind and mind, so that here it is beneficial for the community as well as for maintenance as a whole.

\section{B. LITERATUR REVIEW}

\section{Industrial Area}

The industry is a monetary action that measures raw merchandise, raw materials, products, or goods that are still half-finished and then developed into goods with added value, as stated by Sadono. (Sukirno, 2013). Based on the National Industrial Zoning Committee (NIZC), Industrial Estates are defined as gathering various types of industry in an area with various factory supporting facilities that are accommodated and supervised by industrial mechanisms either from the private sector or the government directly supervising different mechanical exercises. It 
Islamiconomic: Jurnal Ekonomi Islam Vol.12 No.1 January - June 2021

characterizes a modern zone as an area or zone with a mix of offices consisting of mechanical factories, business premises, and other foundations, such as social offices and public offices. The advancement of the current domain is proposed so that the effects and advantages of mechanical existence can be controlled by a single administrative unit to effectively carry out its duties. However, limited characteristics convey limits such as distinct effects because mechanical cycles are resolved in a "nothing new" manner to have empowered public authorities and business people to devise ideas equipped approaches to synergize financial development with constrained normal assets and natural security measures.

\section{Halal Industry}

Halal in language, as indicated in certain conclusions, comes from the root word

الحل which has the meaning (الإباحة) which means something that is permissible. as indicated by the Shari'a. Al-Jurjaani's composition, "halal" (الحل) or "open" (الفتح) which are words, implied by any means which cannot be penalized for their use or demonstrations which are freed by law to resolve. (حلال) implies being separated or freed (طلقا) explains that halal is something that can be done, there is no prohibition in Islamic law, and those who do it do not get sin from Allah SWT. Meanwhile, an item that is halal is an item that has been processed first, and the raw material has met the criteria described by the Sharia and does not contain any prohibited elements. (Rohaeni \& Sutawijaya, 2020). The meaning of the word halal can be concluded as something that can be done according to sharia, and if it is related to food, it can be consumed and if goods can be used in increasing government assistance to the community, both through handling raw materials, and creating different perspectives that can become financial items permitted by sharia, regardless of whether during the production, business, use, performance or progress that is spent not the consequences of mu'amalah gymnastics are prevented. 
Fitra Azkiya. F et al.: Implementation of Green Supply Chain...

\section{Halal Supply Chain}

One of the important performance factors for maintaining the company's existence must be maximized as best as possible to achieve the company's goals or vision. Therefore. Maintaining the company's performance following the flow and conducting regular performance measurements, in the meaning of the halal supply chain, its performance's quality and results must be continuously monitored concerning effectiveness and efficiency to maintain integrity so that consumers are sure of this halal supply chain (Tieman, 2011). Several methods are commonly used in measuring the performance results of supply chain management, namely data envelopment analysis, balanced scorecard, and SCOR.

A halal shop chain, the board, controls the supply of raw materials for the manufacture, handling, display, progress, and ready-to-burn goods following halal principles. In general, there are four basic exercises in the halal production network, namely:

1. Halal (Procurement). The acquisition of halal goods is a way of obtaining halal raw materials that include inclusion in exercises that emphasize maintaining halal respect throughout the store chain. The halal assessment of raw materials is not only based on halal material, but the source and installation framework are also halal.

2. Halal Manufacturing (Processing) Halal handling is a way of converting raw materials into goods according to the methodology according to halal guidelines. The treatment cycle is the stage most at risk of causing non-halalness. In line with that, it is essential to strengthening the use of the sharia framework in the internal preparation organization.

3. Halal distribution. Halal appropriation consists of bundling and holding of halal goods. The main trademark in bundling, whether it is an ingredient, must be lawful and acceptable.

4. Halal Logistics. Coordination includes arranging, ensuring, and differentiating goods and materials. The predicate of halal is not only for the goods but also for the size of distribution and presentation for the halal goods inventory network. (Talib \& Johan, 2012). 
Islamiconomic: Jurnal Ekonomi Islam Vol.12 No.1 January - June 2021

Muhammad Abdul Mannan in "Islamic Economics: Theory and Practice" "The problem of Islamic finance is a sociology that contemplates the monetary problems of society which are infused with Islamic qualities" (The aspect of Islamic finance is sociology that examines individual financial problems which are saturated with Islamic qualities)(Menita, 2017). As for standards in Islamic Economics, in particular: 1) The Principle of Tawheed (Faith), 2) Principles of Adl (Justice), 3) Guidelines for Nubuwwah (Prophethood), 4) Khilafah Standard (Government), and 5) Ma'ad Rules (Result).

The capability of the halal industry in this world is extraordinary. This economic opportunity also drags countries with minority Muslims and competes with each other to face the capabilities of sharia business. Based on the 2016/2017 Global Islamic Economy Report, the estimated Muslim dietary use and lifestyle area on the halal planet is \$ 1.9 trillion since 2015 and continues to increase to \$ 3 trillion in 2021. "The world Islamic Economy Report" in 2016/2017 Malaysia is at the top followed by the UAE, then Bahrain which is separated at the highest level as the most developed country in the halal business on the planet. (Rasyid, 2017). So far, the halal industry in Indonesia is also contained in Law Number 33 of 2014 concerning Halal Product Guarantee (JPH), namely: Food and drink, Treatment, Beauty agent, Compound items, Natural stuff, Hereditary design items, and Valuable merchandise that is used. (Republik Indonesia, 2014).

\section{Affirmative Nature of Humans and the Environment}

Humans are equipped with minds and feelings; humans have the mandate as Khalifah on earth in order to stay away from the destruction of nature. The meaning of caliph does not mean destroying and shedding blood, as the angel claims, but building a peaceful, prosperous, and just civilization. Allah SWT. Knowing the potential possessed by humans so that they prioritize it from angels who, in fact, are God's creatures who always carry out whatever is ordered in the Koran to stay away from evil. The angels never denied Allah at all when Allah informed us that humans would be made caliphs on earth. They questioned Allah. This point is clearly illustrated in the Quran. 
Fitra Azkiya. F et al.: Implementation of Green Supply Chain...

So far, many have started the ecology and environmental ethics movement. This has confirmed the destruction of nature and environmental damage due to daily human activities, which are more inclined towards personal gain without any improvement. The understanding of anthropocentric is the cause of the imbalance of the relationship between nature and humans. Even though ecology and environmental ethics have been widely voiced, there is still a dichotomy among the understanding of eco-centrism and anthropocentrism. This is the reason why humans and nature cannot coexist; for example, the community needs land for housing or clearing land. At least the perspective in society must be changed with a new perspective to be built on understanding nature in a substantial perspective, not just the beginning of damage or other symptoms of a statistical, descriptive, or ethical nature. (Dewi, n.d.).

\section{Green Supply Chain Management (GSCM)}

The term GSCM itself generally focuses more on the characteristics of the environment, processes, and sustainability. GSCM has main characteristics in business sustainability, including economic, environmental, social, policy stakeholders, and a long-term focus. (Ahi \& Searcy, 2013). on lean manufacturing, much associated with activities to a production process where something that does not provide added value will be eliminated. Good activity in an industry that only focuses on something that provides added value. Meanwhile, activities that do not provide added value will be eliminated. This process will provide efficiency in the production process so that it will be economically beneficial. The application of GSCM also has a positive impact, especially in terms of economic value. This has begun to develop understanding and consumer awareness of several environmental issues lately so that this will attract consumers' attention in selling a product. Besides that, social issues will also benefit the community by preserving the environment in which they carry out their daily activities.

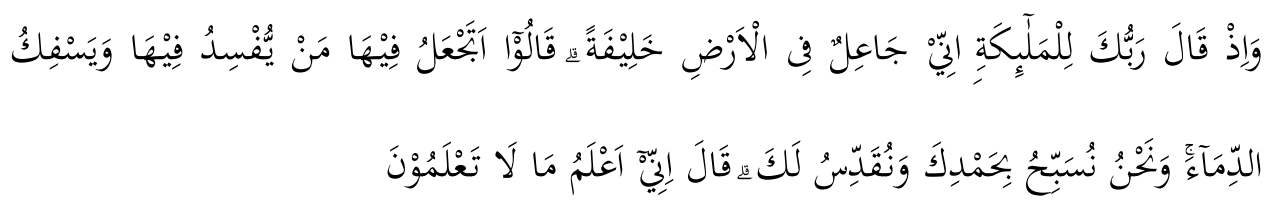


"Remember when your Lord said to the angels: 'Verily I want to make a caliph on the face of the earth.' They said: 'Why do you want to make (caliph) on earth a person who will cause damage to him and shed blood, even though we always praise him You and sanctify You? 'The Lord said:' Verily I know what you do not know". (Q.S. Al-Baqorah 2: 30). (Departemen Agamag RI, 2020).

The above verse is at the same time an order for us to preserve and prosper the earth on which it is a foothold in wise ways and do not damage the environment, for example, by carrying out agricultural, plantation, fishery activities. Allah SWT. Expressly prohibits all forms of destruction of this universe.

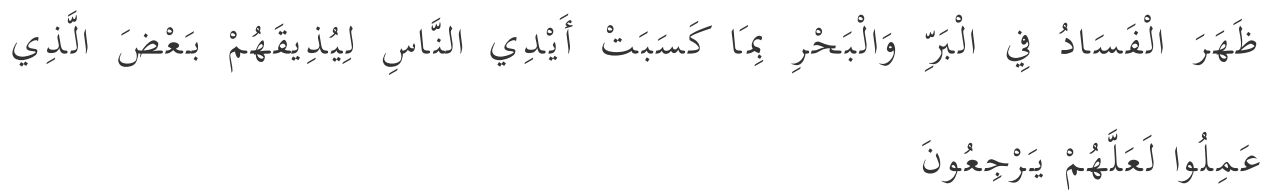

"It has been seen that the damage on land and at sea was caused by the actions of human hands so that Allah will feel for them a part of (the result) of their actions so that they will return (to the right path)" (Q.S. Al-Ruum 30: 41). (Departemen Agama RI, 2020).

Image 1. Green Supply Chain Management

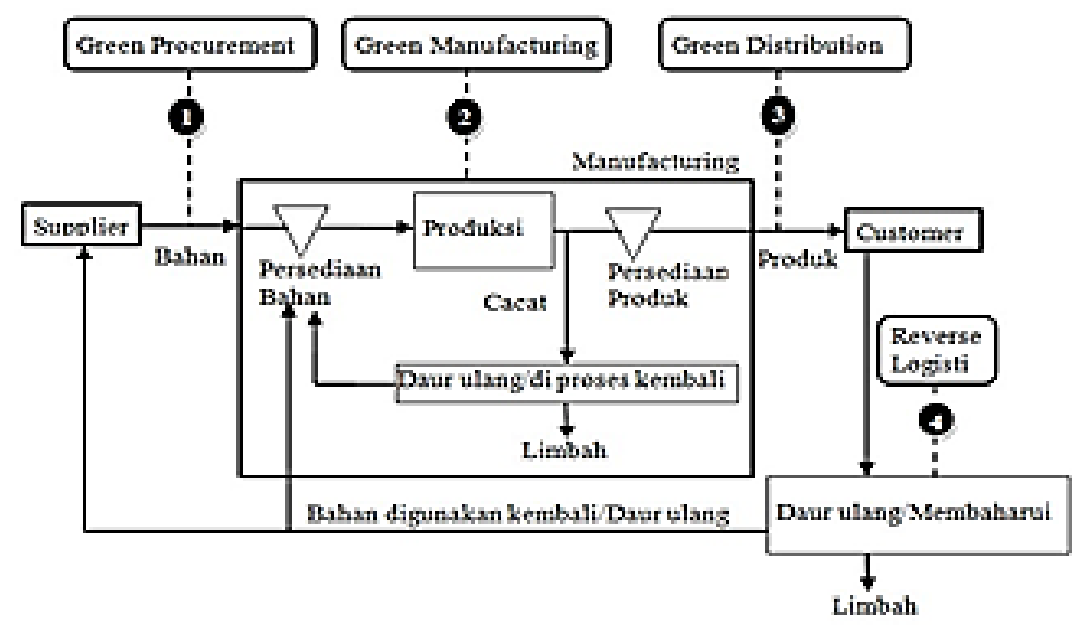

Source: (Puryono et al., 2017) 
Fitra Azkiya. F et al.: Implementation of Green Supply Chain...

Damage to the ecosystem is human-made. Human nature that is always greedy, greedy, tyrannical, and so on is the ugly side of humans. From the perspective of humanism, environmental damage and imbalance occur due to humans putting their egos forward too much and wanting to control everything. (Rosowulan, 2019). Moreover, indeed, Allah has pinned two contradictory traits in humans. Both of them will always fight to dominate humans. Therefore, in order for domination to be won by good character, it must always be honed with divine wisdom and spiritual values according to Islamic law.

\section{METHODOLOGY}

Writing this scientific paper uses a method, namely literature study with the following stages: Testing the quality of the study, the process of collecting and sorting data according to the intended object, data analysis, interpretation of the results, and recommendations of the research results. The data obtained included qualitative data and quantitative data. from various published research sources, books, legislation, and other literature.

The data is processed through descriptions of research variables from various study sources and then presented in a descriptive narrative form in the form of paragraphs. so that the results of the data obtained have an explanation. This paper analyzes and evaluates the Halal Supply Chain Management model as a product supply chain method in the existing halal industrial area and the area of the halal industry that is being initiated and built. Some cases have similar variables in the methods, assessment instruments, and solutions applied.

\section{RESULT AND ANALYSIS}

The absence of a sustainable government policy between the concepts of industrial estates, in this case, the green industry concept, was implemented first, then the concept of a massive halal industrial area is planned recently in various regions in Indonesia. Does not provide solutions to the progress of industrial development. The halal industry itself emphasizes the halal aspect, while the green industrial area emphasizes the environmental aspects. So here is the need for continuity between pre-existing concepts. So that the halal industrial area is not only 
concerned with halal but also pays attention to environmental aspects for the sake of preserving the natural ecosystem, of course by protecting nature we also avoid the harm that results from environmental damage such as floods, landslides, and other disasters.

The concept to be developed emphasizes more on providing improvements in the halal industry to achieve the concept of Halalan Thoyyiban in Islamic teachings. This improvement leads to natural factors for environmental sustainability and natural preservation. So that we, the Muslim community in general, can apply all aspects both in our daily mu'amalah. Of course, this new concept is inseparable from policy support from the government so that the regulations that emerge can be immediately applied, be it a halal industrial area or a separate manufacturing company that adheres to and implements the halal industry.

\section{Image 2. Model of Halal Supply Chain Management}

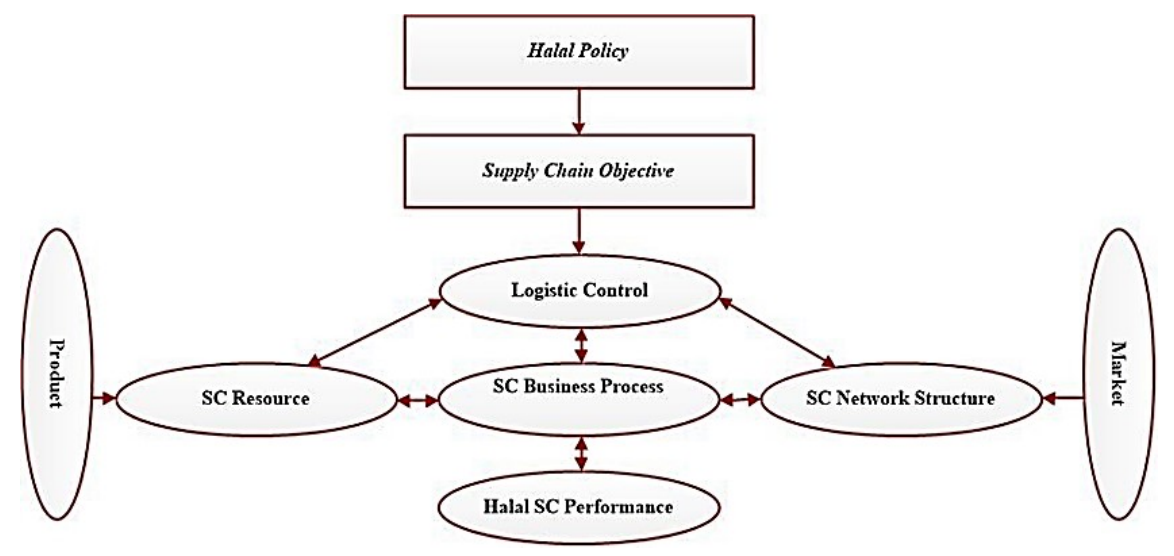

Source: (Tieman et al., 2012)

The Halal supply chain management model developed by Tieman et al has not been able to deal with various environmental issues. In the peer-to-peer model scheme, halal supervision is at the top. The process of halal supervision is also contained in the process of halal ability in the final product of a product in the supply chain. This of course does not address various environmental issues in the product production process. Recently, environmental issues have also become an important issue and are often discussed in various international forums. 


\section{Image 3. Conceptual Model of Halal Supply Chain Management}

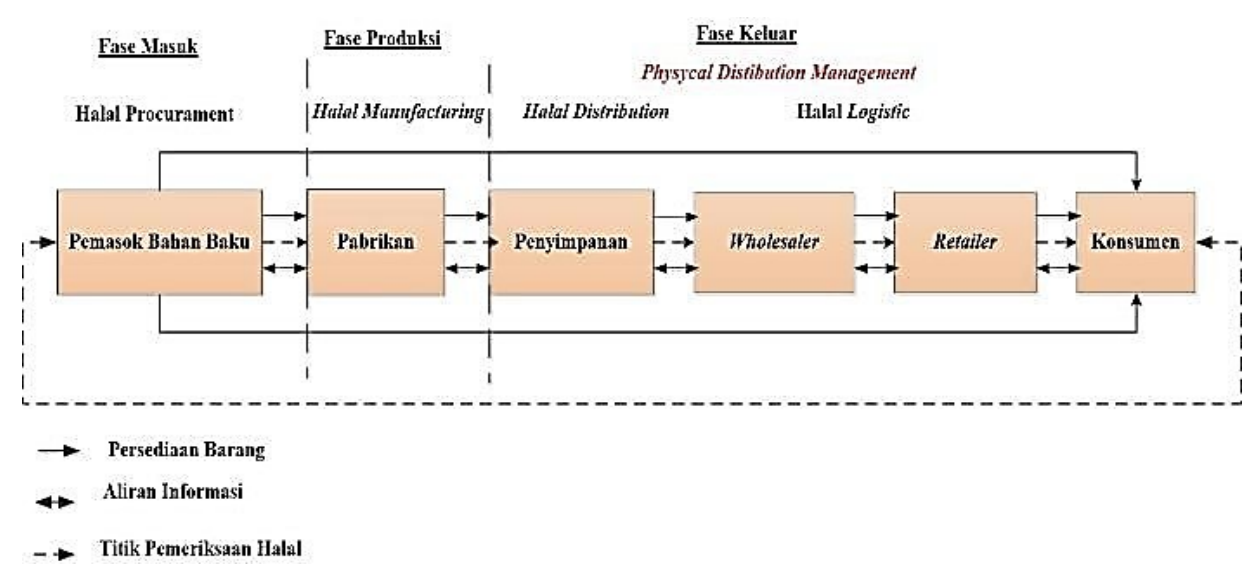

Source: (Rasi et al., 2017)

Another model of Halal supply chain management developed by Rasi et al, also have not made any demands on following environmental and natural sustainability issues. The four phases of halal in the developed scheme, namely halal procurement, halal manufacturing, halal distribution, and halal logistics, have not provided a solution in the production process of an item. Despite the virtue of halal in Islam, humans, and nature also coexist. Humans as caliphs on earth must also participate in protecting nature. In the past few years, the halal industry has been in countries with a majority Muslim population and includes countries with a majority of non-Muslim populations. Therefore, halal products are increasingly popular globally, so we must maintain the halal supply because they are considered to have an essential role in it. This research applies the concept of "Halalan Thoyyiban" to be the primary basis in order to ensure consumers consume an item, where we must know that the item is genuinely halal, starting from supplier goods to processing in the industry using halal methods so that guaranteed that an item is in the hands of the consumer. (Omar \& Jaafar, 2011).

Efficiency, Green Supply Chain Management (GSCM) is being implemented in Indonesia's halal industry, which currently uses Halal Supply Chain Management (HSCM). It can be applied in various industrial areas, including the halal industrial area, which is starting to be widely used by the government. Steps that can be taken to negate this are as follows: 
1. Pre-Production Education Stage

a. holding seminars for industry players on environmental awareness as well as relevant ministerial policy stakeholders in this case who have the most interest in implementing this program

b. Inviting industry players who have implemented Green supply Chain management (GSCM) in various industrial fields in Indonesia, halal industry players

c. Emphasize industry players. First, as a country with an immense Muslim majority globally, it is imperative to emphasize halal products. Second, the sustainability of the ecosystem is related to the use of renewable energy and environmentally friendly raw materials to maintain and avoid harms such as air pollution, water pollution, and other disasters caused by industry in general. Production Stage

d. Substitute raw materials are environmentally friendly and guaranteed to be halal

e. The use of renewable and environmentally friendly energy

f. The production optimization process for reducing waste, emissions, and energy savings

g. Applying the principles of total quality management (Total Quality management)

\section{Post Production Stage}

a. Halal and quality control of finished goods

b. Waste processing in an environmentally friendly manner

c. Recycle damaged products

d. The storage process is following the applicable rules, not hoarding goods so that they are rare

e. Halal distribution process using environmentally friendly transportation with minimal gas emissions. 


\section{Image 4. Conceptual Model Manufacturing Process Implementation of Green} Supply Management in Halal Supply Chain Management

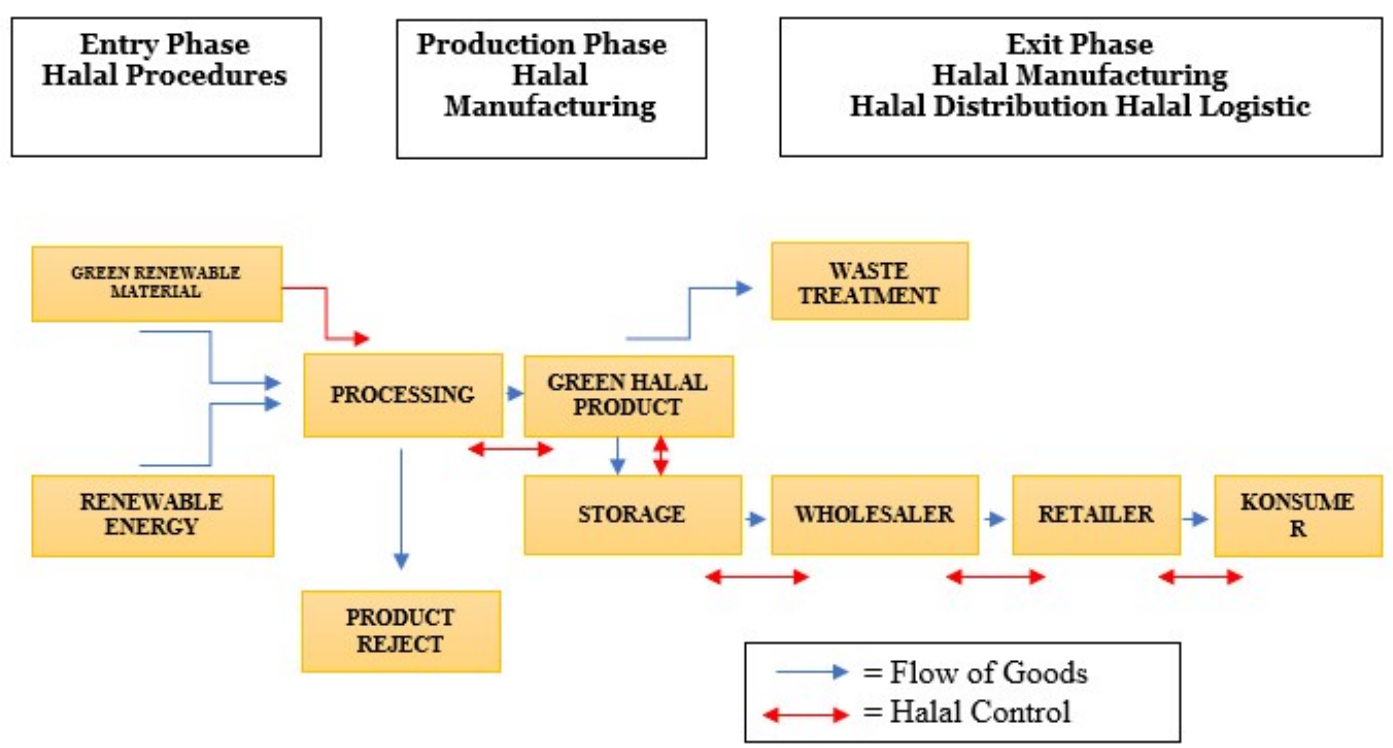

We can assume this scheme more concisely:

1. The entry phase. Starting from the process of procuring raw materials, already using environmentally friendly materials that are guaranteed to be halal. In addition, at the beginning the use of energy also used renewable or non-fossil energy

2. Production Phase. In the production process, it is also subject to halal supervision. If the product does not pass the halal or minimum standard of a product, then the product is rejected and it is not fit for circulation

3. Exit Phase. In the final phase, environmentally friendly halal products will go through the storage process, to the distribution process with the supervision of halal standards, besides that the vehicles used have also passed the emission test. In this phase, the waste products must also be processed so that they are not the benefits obtained when Green supply chain management are implemented in the halal industry which prioritizes Halal supply chain management. 


\section{Image 5. Advantages in the Implementation of Conceptual Model Green Supply Management in Halal Supply Chain Management}
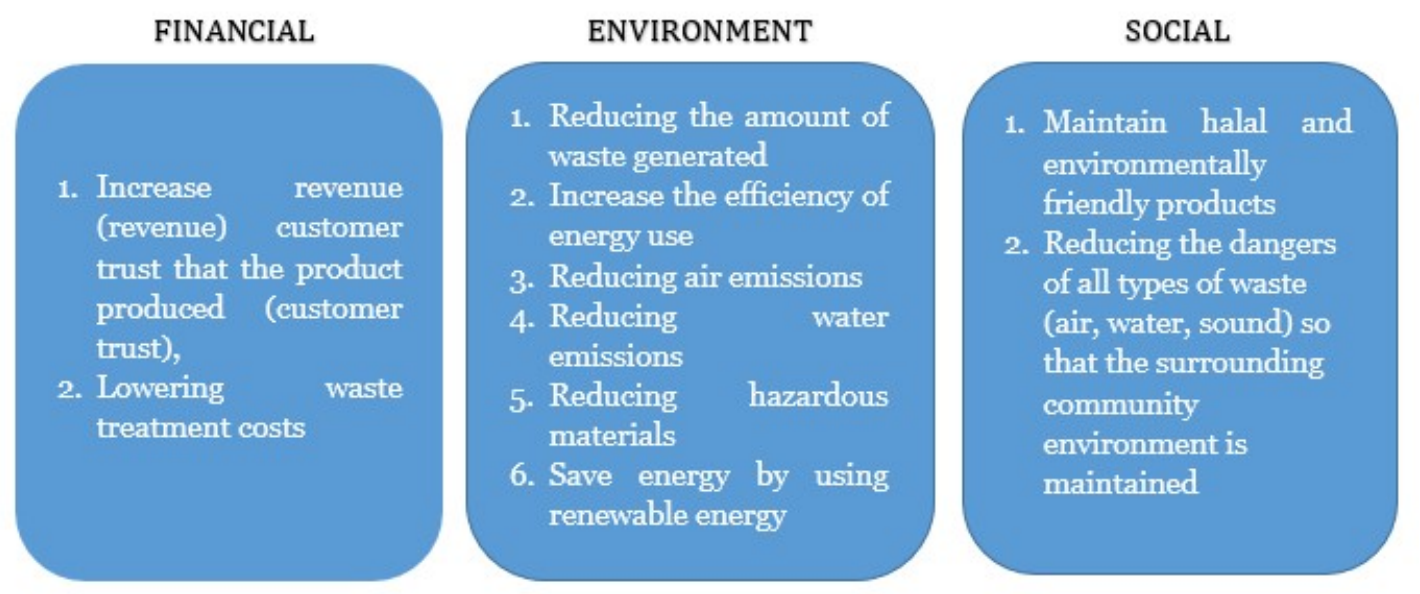

The advantages can be divided into three parts, namely:

1. Financial; Increasing revenue is related to customer confidence that the products produced have guaranteed quality with various halal controls and with environmentally friendly mechanisms (customer trust), at the beginning of this concept, raw materials or substitutes for an environmentally friendly product have been used so that the resulting waste will also be better than environmentally unfriendly raw materials. Of course, this will reduce waste treatment costs,

2. Environment; The main focus in this concept is halalan thoyyiban so that what is involved in the production process focuses on reducing various negative impacts on the environment, among others. Reducing the amount of waste generated, Increasing the efficiency of energy use, Reducing air emissions, Reducing water emissions, Reducing hazardous materials, Saving energy with the use of renewable energy,

3. Social; Maintain halal and environmentally friendly products, reduce the dangers of all types of waste (air, water, sound) so that the environment is maintained, this can preserve flora and fauna, whereas if the factory is close to residential areas it will participate in maintaining a healthy environment in people's lives around. 


\section{Discussion}

\section{Regulatory Readiness}

There are other things that also influence the development of this concept if implemented. In its implementation, the halal industry is also inseparable from the current regulations, especially in Indonesia which are also guided by the law as well as the BPJH and MUI fatwas. The halal industry itself is based on Law Number 33 of 2014 concerning “Guaranteed Halal Products” Chapter 1, Article 1, Paragraph 1, "Products are goods and/or services related to food, beverages, medicines, cosmetics, chemical products, biological products. , genetically engineered products, as well as used goods that are used, used, or utilized by the community"(Republik Indonesia, 2014). Then there are derivative regulations in Government Regulation No.31 of 2019, which contain more detailed regulations related to technical implementation in the field(Presiden RI, 2019). The halal industry is regulated in the Minister of Industry Regulation No. 17 of 2020 concerning How to Obtain a Certificate in the Context of the Establishment of a Halal Industrial Zone.(BPJPH, 2020).

The latest regulation in the draft Employment Copyright Law, related to obtaining a halal certificate in Article 29 paragraph (3) has changed in the period for checking and filing for certification is now cut to a span of one working day 48 regulates the guarantee of halal products. Regarding the authorized institutions, there are several related bodies, namely the halal product guarantee agency (BPJPH) and halal auditors, and halal inspection agencies. Meanwhile, MUI is the one who gives fatwas after all the processes have been carried out.

\section{Halal Industrial Area Readiness}

Recently, industrial estates have been intensively created by the government. This halal industrial area will later implement halal supply chain management, the concept that the researchers developed is of course also related to industrial areas, where the implementation of the environmentally friendly HSCM model must be applied in one industrial area, not only in one particular factory. Halal supply chain service provider perspective provides an overview of Halal supply chain adoption by Halal producers for transportation and warehouse operations. Halal logistics service 
Islamiconomic: Jurnal Ekonomi Islam Vol.12 No.1 January - June 2021

providers build halal supply chains to meet the needs of halal suppliers and maintain halal integrity for halal goods (Ngah et al., 2014). The view in the halal industry is currently in an uproar and booming since the launch of Halal certification. However, there are still deficiencies in the implementation of the halal industry, namely not including environmental aspects.(Hashim \& Shariff, 2016).

\section{Side by side with Nature}

As a Muslim, of course, we understand that humans are caliphs on earth, this is clear and found in Q.S. Al-Baqorah 2: 30. further, Q.S. Al-Ruum 30: 41 explains that the damage has occurred on land and on earth. This is evidence that humans are the main actors in environmental destruction. Therefore, the concept of halal also has to adapt to natural conditions, so that the benefits felt are greater. The main concern in developing this halal model of supply chain management is to deal with various environmental issues, many ecological movements have started in various aspects of life human. Environmental issues are global issues in response to climate change. Therefore, local business actors must also participate in this readiness to compete globally. Developed countries have already implemented this.

So far, the basis for implementing the green industry is the 2014 Law on Industry CHAPTER 1 ARTICLE 1 paragraph 3 states "Green Industry is an industry which in its production process prioritizes efficiency and effectiveness in the use of resources in a sustainable manner so that it can harmonize industrial development with sustainable functions. Environment and can provide benefits to the community". Then there are the derivative rules, namely. Regulation of the minister of industry No. 41 of 2017 concerning Green Certification Agencies Then continued No. 39 the Year 2018 concerning Green Industry Certification Procedures. (Peraturan Menteri Perindustrian Republik Indonesia Nomor 39 Tahun 2018 Tentang Tata Cara Sertifikasi Industri Hijau, 2018).

The following lean, resilient, and environmentally friendly supply chain management practices have no significant impact on supply chain sustainability: "flexible transportation," "flexible sourcing," "ISO 14001 certification," and "reverse logistics." provides a taxonomy for lean, resilient, and environmentally friendly supply chain management practices at three levels: upstream, organizational, and 
Fitra Azkiya. F et al.: Implementation of Green Supply Chain...

downstream(Govindan et al., 2014). Green supply chain management (GSCM) and critically evaluating research and future directions for implementation in the field. (Sarkis et al., 2011).

This is evident in combining green supply chain practices that link producers with partners linked to this green supply chain, such as raw material suppliers and consumers. Manufacturing managers provide data that reflects the extent to which their organizations work with suppliers and customers to improve the supply chain's environmental sustainability. Generally, the adoption of GSCM practices by manufacturing organizations leads to improved environmental performance and economic performance, which has a positive impact on operational performance. (Green et al., 2012a). Internal environmental management and green information systems were identified as necessary precursors to adopting green purchasing, customer collaboration, green design, and investment recovery. Originality/value - A comprehensive GSCM practice performance model is proposed and assessed empirically. The results of this investigation support the proposition that GSCM practices are an environmentally necessary and sound business. (Green et al., 2012b).

The relationship between GSCM practices such as supplier selection, supplier assessment, environmental cooperation, internal environmental practices, environmentally friendly product and process design, and sustainability efficiency. The findings that environmental cooperation, internal environmental policies, environmentally friendly goods, and process design all have a mostly positive relationship with sustainability efficiency. The most reliable predictors of environmental success are environmentally friendly packaging practices and process design. Surprisingly, supplier selection and assessment had little impact on sustainability outcomes. This report's conclusion is significant for manufacturers who want to include GSCM activities in their industry to achieve sustainability(Green et al., 2012b).

\section{Increase Corporate Reputation}

Green supply chain management practices affect the reputation of companies, one of which is the chemical industry in Jordan. The results show that green supply chain management practices have a direct effect on a company's reputation, and the 
Islamiconomic: Jurnal Ekonomi Islam

Vol.12 No.1 January - June 2021

researchers suggest that managers and policymakers use these findings to adopt green supply chain practices that allow businesses to reap multiple benefits, such as getting more company permits. effective and obtain funds for investment. (Al-Ghdabi et al., 2019).

\section{Resource Readiness}

Supervision as well as in preparing human resources in the halal production process takes time, therefore in the process of preparing the implementation of this concept training is needed. As has been explained in (Sulaiman et al., 2018), that a company or organization needs a special committee that understands all aspects to be able to declare halal. Industry players must first understand a halal industrial area. Because most of the owners of companies or companies that will be engaged in this field are not fully labeled as Islamic, but rather aim at general companies. Another factor is the halal certification process on the results of the production goods itself which is an important part, where this also depends on the process of applying for halal certification to MUI.

\section{E. CONCLUSION}

There are four important activities in the supply chain management of the halal industry, namely: halal procurement, halal processing, halal distribution, and halal logistics. Meanwhile, in the management of the green industry supply chain itself. prioritizing, efficiency in the use of resources such as non-fossil electrical energy, efficient use of water, raw materials for a product or raw materials for an environmentally friendly substitute, the resulting waste must be processed further, air and noise pollution also need to be minimized, so that the does not damage the environmental ecosystem. plants and animals found in industrial areas can also be preserved. This also applies to industrial areas that are close to residential areas so that the surrounding population is not disturbed.

The implementation of the green supply chain management concept will complement the halal supply chain management. Practices in Islamic economics, of course, prioritize halalness. The production process of Halal goods from processing raw materials to becoming more valuable goods, in halal supply chain management is 
Fitra Azkiya. F et al.: Implementation of Green Supply Chain...

not only in the production process but also in the logistics and distribution process, there is also halal supervision. Halal is reflected in Halal Supply Chain Management, while Green Supply Chain Management reflects thoyyiban (good) in the environment. The two concepts become one unit in "halalan thoyyiban". So that the results of implementing environmentally friendly concepts in the supply chain of the halal industry have many positive impacts in three major aspects, namely. Financial, Environmental, and Social. What is aspired in Islamic economic practice can be achieved, namely Halal and good for environmental sustainability, while for the corporation it also provides efficiency in the three aspects mentioned above.

The results of this research can be used as input for corporations so that the concepts offered can be put into practice, for Muslim communities, in general, to actively participate in monitoring the halalness of a product and be active in various environmental issues. Finally, the results of this study can be taken into consideration for policymakers in making better regulations

\section{F. REFERENCES}

Ahi, P., \& Searcy, C. (2013). A comparative literature analysis of definitions for green and sustainable supply chain management. Journal of Cleaner Production. https://doi.org/10.1016/j.jclepro.2013.02.018

Al-Ghdabi, R. R., Almomani, R. Z. Q., \& Banyhamdan, K. M. (2019). Impact of the green supply chain management practices on corporate image of chemical industries in jordan. International Journal of Scientific and Technology Research, 8(12), 25462554.

BPJPH. (2020). BPJPH - LPH LPPOM MUI Sinergi dalam Fasilitasi Sertifikasi Halal UMK. Badan Penyelenggara Jaminan Produk Halal.

Departemen Agamag RI. (2020). Al Quran dan terjemahan. In Al-Qur'an Terjemahan.

Dewi, S. (n.d.). Ekofenomenologi: Mengurai Disekuilibrium Relasi Manusia dengan Alam (2015th ed.). Marjin Kiri.

Govindan, K., Azevedo, S. G., Carvalho, H., \& Cruz-Machado, V. (2014). Impact of supply chain management practices on sustainability. Journal of Cleaner Production. https://doi.org/10.1016/j.jclepro.2014.05.068

Green, K. W., Zelbst, P. J., Meacham, J., \& Bhadauria, V. S. (2012a). Green supply chain 
Islamiconomic: Jurnal Ekonomi Islam Vol.12 No.1 January - June 2021

management practices: Impact on performance. Supply Chain Management. https://doi.org/10.1108/13598541211227126

Green, K. W., Zelbst, P. J., Meacham, J., \& Bhadauria, V. S. (2012b). Green supply chain management practices: Impact on performance. Supply Chain Management, 17(3), 290-305. https://doi.org/10.1108/13598541211227126

Hashim, H. I. C., \& Shariff, S. M. M. (2016). Halal Supply Chain Management Training: Issues and Challenges. Procedia Economics and Finance. https://doi.org/10.1016/s2212-5671(16)30089-2

Menita, H. A. (2017). PEMIKIRAN ABDUL MANNAN TENTANG EKONOMI ISLAM. AlIntaj.

Ngah, A. H., Zainuddin, Y., \& Thurasamy, R. (2014). Adoption of Halal Supply Chain among Malaysian Halal Manufacturers: An Exploratory Study. Procedia - Social and Behavioral Sciences, 388-395. https://doi.org/10.1016/j.sbspro.2014.03.692

Nurfadhila, A., \& Suganda, A. (2021). INTENSITAS KUNJUNGAN WISATA RELIGI MENJADI PENENTU PENDAPATAN STREET VENDORS KAWASAN MASJID AGUNG BANTEN LAMA. I-ECONOMICS: A Research Journal on Islamic Economics, 7(1), 23-36. https://doi.org/https://doi.org/10.19109/ieconomics.v7i1.8990

Oliver, R. K., \& Webber, M. D. (2012). Supply-Chain Management: Logistics Catches up with Strategy. In The Roots of Logistics. https://doi.org/10.1007/978-3-64227922-5_15

Omar, E. N., \& Jaafar, H. S. (2011). Halal supply chain in the food industry - A conceptual model. ISBEIA 2011 - 2011 IEEE Symposium on Business, Engineering and Industrial Applications. https://doi.org/10.1109/ISBEIA.2011.6088842

Peraturan Menteri Perindustrian Republik Indonesia Nomor 39 tahun 2018 tentang Tata Cara Sertifikasi Industri Hijau. (2018).

Presiden RI. (2019). Peraturan Pemerintah Republik Indonesia Nomor 31 Tahun 2019 Tentang Peraturan Pelaksanaan Undang-Undang Nomor 33 Tahun 2014 Tentang Jaminan Produk Halal. Presiden Republik Indonesia, 8(5), 55.

Puryono, D. A., Mustafid, M., \& Jie, F. (2017). Penerapan Green Supply Chain Management Untuk Peningkatan Kinerja Keuangan Perusahaan. Jurnal Sistem 
Fitra Azkiya. F et al.: Implementation of Green Supply Chain...

Informasi Bisnis, 6(2), 154. https://doi.org/10.21456/vol6iss2pp154-163

Raj, A., Biswas, I., \& Srivastava, S. K. (2018). Designing supply contracts for the sustainable supply chain using game theory. Journal of Cleaner Production. https://doi.org/10.1016/j.jclepro.2018.03.046

Rasi, R. Z., Masrom, N. R., Omar, S. S., Ahmad, M. F., \& Sham, R. (2017). Withdrawn article: Designing Halal Supply Chain: Malaysia's Halal Industry Scenarios. $\begin{array}{llll}\text { MATEC Web } & 00040 .\end{array}$ https://doi.org/10.1051/matecconf/201713500040

Rasyid, H. Al. (2017). Pengaruh Kualitas Layanan Dan Pemanfaatan Teknologi Terhadap Kepuasan Dan Loyalitas Pelanggan Go-Jek. Jurnal Ecodemica: Jurnal Ekonomi, Manajemen, Dan Bisnis. https://doi.org/10.31311/jeco.v1i2.2026

Republik Indonesia. (2014). Undang - Undang Republik Indonesia U No. 33 Tahun 2014 tentang Jaminan Produk Halal. Undang - Undang Republik Indonesia.

Rosowulan, T. (2019). Konsep Manusia dan Alam Serta Relasi Keduanya dalam Perspektif Al-Quran. Cakrawala: Jurnal Studi Islam. https://doi.org/10.31603/cakrawala.v14i1.2710

sadono sukirno. (2013). Makroekonomi: Teori Pengantar. Rajawali Pers.

Sarkis, J., Zhu, Q., \& Lai, K. H. (2011). An organizational theoretic review of green supply chain management literature. In International Journal of Production Economics. https://doi.org/10.1016/j.ijpe.2010.11.010

Sulaiman, S., Aldeehani, A., \& Aziz, F. A. (2018). Integrated Halal Supply Chain System In Food Manufacturing Industry. Journal Of Industrial Engineering Research, 4(3), $1-5$.

Talib, M. S. A., \& Johan, M. R. M. (2012). Issues in Halal Packaging: A Conceptual Paper. International Business and Management. https://doi.org/10.3968/j.ibm.1923842820120502.1080

Tieman, M. (2011). The application of Halal in supply chain management: In-depth interviews. Journal of Islamic https://doi.org/10.1108/17590831111139893

Tieman, M., van der Vorst, J. G. A. J., \& Ghazali, M. C. (2012). Principles in halal supply chain management. Journal of Islamic Marketing. https://doi.org/10.1108/17590831211259727 
Islamiconomic: Jurnal Ekonomi Islam Vol.12 No.1 January - June 2021

UU. No 3. (2014). Undang-Undang No 3 tahun 2014 Tentang Perindustrian. In Cell.

Yeni Rohaeni, \& Ahmad Hidayat Sutawijaya. (2020). Pengembangan Model Konseptual Manajemen Rantai Pasok Halal Studi Kasus Indonesia. J@ti Undip : Jurnal Teknik Industri, 15(3), 177-188. https://doi.org/10.14710/jati.15.3.177188

Yulia, Lady. (2015). Halal Products Industry Development Strategy Strategi Pengembangan Industri Produk Halal. Jurnal Bisnis Islam, 8(1), 121-162.

UU. No 3. (2014). Undang-Undang No 3 tahun 2014 Tentang Perindustrian. In Cell.

Republik Indonesia. (2014). Undang - Undang Republik Indonesia U No. 33 Tahun 2014 tentang Jaminan Produk Halal. Undang - Undang Republik Indonesia.

Presiden RI. (2019). Peraturan Pemerintah Republik Indonesia Nomor 31 Tahun 2019 Tentang Peraturan Pelaksanaan Undang-Undang Nomor 33 Tahun 2014 Tentang Jaminan Produk Halal. Presiden Republik Indonesia, 8(5), 55. 